\title{
Electrophoretic study on intraspecific variations and interspecific relationships of marine catfishes (Siluriformes, Ariidae) of Cananéia (São Paulo, Brazil). 1. General proteins of eye-lens and skeletic muscle
}

\author{
Hana SUZUKI \& PHAN Van Ngan
}

Instituto Oceanográfico da Universidade de São Paulo

(Caixa Postal 9075, 01051 São Paulo, SP)

- Abstract: Cellulose acetate electrophoresis of eye-lens proteins and polyacrylamide flat gel electrophoresis of skeletic muscle proteins of six species of marine catfishes were carried out. Genetic polymorphism only occured at one locus of the electropherograms of eye-lens of Cathorops spixii. Ontogenetic variations in the relative concentration of bands were found in the electropherograms of eye-lens and skeletic muscle proteins. The six species of catfishes can be identified by means of quantitative and qualitative differences in the electropherograms. Coefficients of similarity were determined by the band-counting method and UPGMA dendrograms were constructed to illustrate the interspecific relationships among the species.

- Descriptors: Electrophoresis, Proteins, Muscles, Eye-lens, Interspecific relationships, Ariidae, Cananéia, Brazil.

Descritores: Eletroforese, Proteínas, Músculos, Cristalino, Relaçōes interespecíficas, Ariidae, Cananéia: SP.

\section{Introduction}

The family Ariidae is comprised of catfishes, mainly marine and estuarine forms, with a world-wide distribution in warm temperate and tropical waters. These catfishes occur along the whole Brazilian coast where they usually occur on muddy and sandy bottoms (Figueiredo \& Menezes, 1978).

Concerning the systematics of ariid catfishes, there is considerable controversy about the number of species and genera, mainly for the Atlantic species (Higuchi, 1982). Reports on occurrences of marine catfishes in the Brazilian coast (Ribeiro, 1911; Carvalho, 1941; Fowler, 1941, 1951; Gosline, 1945; Puyo, 1949; Tommasi, 1965; Poli, 1973; Taylor \& Menezes, 1977; Figueiredo \& Menezes, 1978), sometimes refer to the same species by different scientific names. The necessity of a revision in the systematics of the family Ariidae, mainly at supra-specific levels, is pointed out by Higuchi (1982) and Higuchi et al. (1982).

Electropherograms of eye-lens proteins have been a useful tool in identification of species (Calhoun \& Koenig, 1970; Pichot \& Pollard, 1970; Smith, 1970; Pichot, 1973; Pichot \& Pichot, 1973; Weinstein \& Yerger, 1976; Smith \& Gilman, 1982), as well as in delimitation of

$\overline{\text { Contr. } n^{2} 714}$ do Inst. oceanogr. da Usp. populations of various species of fish (Smith, 1965, 1969, 1971; Smith \& Goldstein, 1967; Eckroat \& Wrigth, 1969; Peterson \& Smith, 1969; Eckroat, 1971, 1973; Saunders \& McKenzie, 1971; Ettabili et al., 1980; Chauvet \& Baeten, 1983).

The use of skeletic muscle in genetic biochemical studies has also been widespread. While the structural proteins of the muscle show great similarity at least among the vertebrates, the sarcoplasmic (or soluble) proteins vary both qualitatively and quantitatively even between closely related species (Scopes, 1968). Electropherograms of soluble proteins of skeletic muscle are useful for taxonomic and evolutionary studies due to their relative intraspecific constancy and species-specificity (Tsuyuki et al., 1965; Westrheim \& Tsuyuki, 1967; Tsuyuki et al., 1967, 1968; Lleonart \& Agell, 1980; Payusova \& Tselikova, 1981).

In this paper, the intraspecific variations and the interspecific relationships among the members of the family Ariidae of the region of Cananéia (São Paulo, Brazil), namely Netuma barba (Lacépède, 1803), Genidens genidens (Valenciennes, 1839), Sciadeichthys luniscutis (Valenciennes, 1840), Cathorops spixii (Agassiz, 1829), Bagre bagre (Linnaeus, 1766) and Bagre marinus (Mitchill, 1814), based on electropherograms of general proteins of eye-lens and skeletic muscle are reported. 


\section{Material and methods}

For the eye-lens analyses, a total of 1388 catfishes was used. In this total there were $428 \mathrm{~N}$. barba, $261 \mathrm{G}$. genidens, 264 S. luniscutis, 387 C. spixii, 39 B. bagre and 9 B. marinus. For the skeletic muscle analyses, a total of 772 catfishes consisting of $221 \mathrm{~N}$. barba, $147 \mathrm{G}$. genidens, 132 S. luniscutis, 237 C. spixii, 28 B. bagre and 7 B. marinus was used. The fishes were collected in the region of Cananéia $\left(25^{\circ} \mathrm{S}, 48^{\circ} \mathrm{W}\right)$ (São Paulo, Brazil) from January 1980 to August 1985.

The eye-lenses were sampled from alive fishes and freed from all adhering tissues. Samples of skeletic muscle were taken from the right side under the dorsal spine of alive animals. The muscle sampling position was standardized in order to minimize quantitative variations in the electropherograms (Suzuki et al., 1983a). Eye-lens and muscle samples were frozen immediately in liquid nitrogen where they were kept for 3-4 days in the field. After this period, the eye-lens were held at $-25^{\circ} \mathrm{C}$ in the laboratory until electrophoretic analyses and the muscle samples, until use within two weeks. This period is known to be harmless for electropherograms of fish muscle (Suzuki et al., 1983a; Taniguchi \& Ishiwatari, 1972; Yamazoe, 1981). Total length, total weight, sex and gonad weight were obtained from each individual. Gonad somatic index (GSI) and factor of condition $\mathrm{K}$ were computed using the equations: GSI $=$ (gonad weight $/$ total weight) $\times 100$ and $K=$ (total weight / total length ${ }^{3}$ ) $\mathrm{x} 10^{5}$, respectively.

Eye-lens extracts were prepared by macerating the sample in $0.9 \% \mathrm{NaCl}$ solution in the proportion of $1: 4$ (weight : volume) by means of an electric homogenizer and centrifugating the homogenate at $3500 \mathrm{rpm}$ for 30 $\mathrm{min}$. The electrophoresis was carried out on cellulose acetate strips (Cellogel, Chemetron, $5.7 \times 14 \mathrm{~cm}$ ) using Tris-glycine buffer $\mathrm{pH} 8.3(0.0495 \mathrm{M}$ Tris and $0.3836 \mathrm{M}$ glycine). $2 \mu 1$ of extracts were applied at $1.5 \mathrm{~cm}$ from the cathodic end of the strip and electrophoresis was carried out at $300 \mathrm{~V}$ for $20 \mathrm{~min}$. The strips were stained in Ponceau $\mathrm{S}(0.5 \mathrm{~g}$ in $100 \mathrm{ml}$ of $5 \%$ trichloroacetic acid) then rinsed in $5 \%$ acetic acid until all free stain was removed.

Muscle samples were macerated by means of an electric homogenizer in glycerol-EDTA-Tris solution $\mathrm{pH}$ 8.7 (Scopes, 1968) in the proportion of 1:2 (weight: volume). The extracts were obtained by centrifugating the homogenate at $9000 \mathrm{rpm}$ for $40 \mathrm{~min}$ at temperature varying from $0^{\circ}$ to $5^{\circ} \mathrm{C}$. The total protein concentration $(\mathrm{g} / \mathrm{dl})$ was determined by means of biuret reaction (Gornall et al., 1949). Electrophoresis was carried out in vertical polyacrylamide flat gel. The methods of electrophoresis and visualization of general proteins of skeletic muscle were those described by Phan et al. (1985). The electrophoresis was carried out at $5^{\circ} \mathrm{C}$. In order to further minimize the heat generated by the electrophoretic system, an inox box containing grinded ice was placed in front of the gel.

Densitometer with $500 \mathrm{~nm}$ filter was used to estimate the relative concentration $(\%)$ of protein bands. Similarities between species were determined by coefficient of similarity S using the band-counting method (Ferguson, 1980) for every pair of species. UPGMA dendrograms (Sneath \& Sokal, 1973) were constructed to illustrate their interspecific relationships.

\section{Results}

Electropherograms of general proteins of eye-lens showed a total of 13 distinct bands for the six species (Fig. 1) and those of skeletic muscle, a total of 22 distinct bands (Fig. 2). The bands were denominated in the ascending order of their anodal migration.

Genetic polymorphism was only found at one locus of the electropherograms of eye-lens proteins of $C$. spixii. The polymorphism occurred at band 6 and the observed phenotypes were interpreted as products of two electromorphs, $6^{100}$ and $6^{140}$ (Fig. 3). Out of 388 C. spixii, 374 presented the homozygous phenotype $100 / 100$, and 14 , the heterozygous phenotype $100 / 140$. The results were tested against the Hardy-Weinberg equilibrium and good correlation was found between the observed and expected frequencies of the phenotypes (Tab. 1). This polymorphism was not related with sex, length and gonad somatic index.

Besides this genetic polymorphism, intraspecific variations were observed regarding quantitative variations in function of body length in the electropherograms of eye-lens and skeletic muscle proteins. In the electropherograms of eye-lens proteins, decreases in function of body length in the relative concentrations of the cathodic bands ( 2 and 3$)$ and increases in those of intermediate migratory $(6,7$ and 8$)$ and anodic bands (11 and 13), were evident in all species. Regarding electropherograms of skeletic muscle, decreases in function of body length in the relative concentrations of bands of fast migration, namely band 20 of $N$. barba, G. genidens, C. spixii, B. bagre and $B$. marinus, and band 21 of $S$. luniscutis, were evident. The relative concentrations (\%) of the bands did not vary in function of sex, gonad somatic index, factor of condition $\mathrm{K}$ and total protein concentration of the muscle extracts.

Despite these intraspecific variations, species specificity was evident in the electropherograms of eye-lens and skeletic muscle proteins of the six taxa studied. Quantitative differences as shown in the densitometric curves together with qualitative differences in the electropherograms of eye-lens were valid means to identify the species (Fig. 1). Although $N$. barb $a$ and $G$. genidens presented electropherograms with eigth bands, each with the same mobility in both species, $N$. barba could be distinguished from $G$. genidens by the density of bands 2 and 3 . In $N$. barba, the former was denser than the latter. As for $S$. luniscutis and $C$. spixii, besides other qualitative features by which these two species could be identified, $S$. luniscutis presented the band 3 denser than bands 2 and 4 while $C$. spixii presented the band 4 notably denser than bands 2 and 3 . The electropherograms of skeletic muscle of N. barba and $G$. genidens were also very similar. They could be distinguished, however, by the band 19 in $N$. barba and by the greater width and higher density of band 10 in $G$. genidens (Fig. 2).

In order to investigate the interspecific relationships among the ariid catfishes, coefficients of similarity S between pairs of species were calculated (Tab. 2) and dendrograms UPGMA resulting from these coefficients were constructed (Figs 4, 5). 


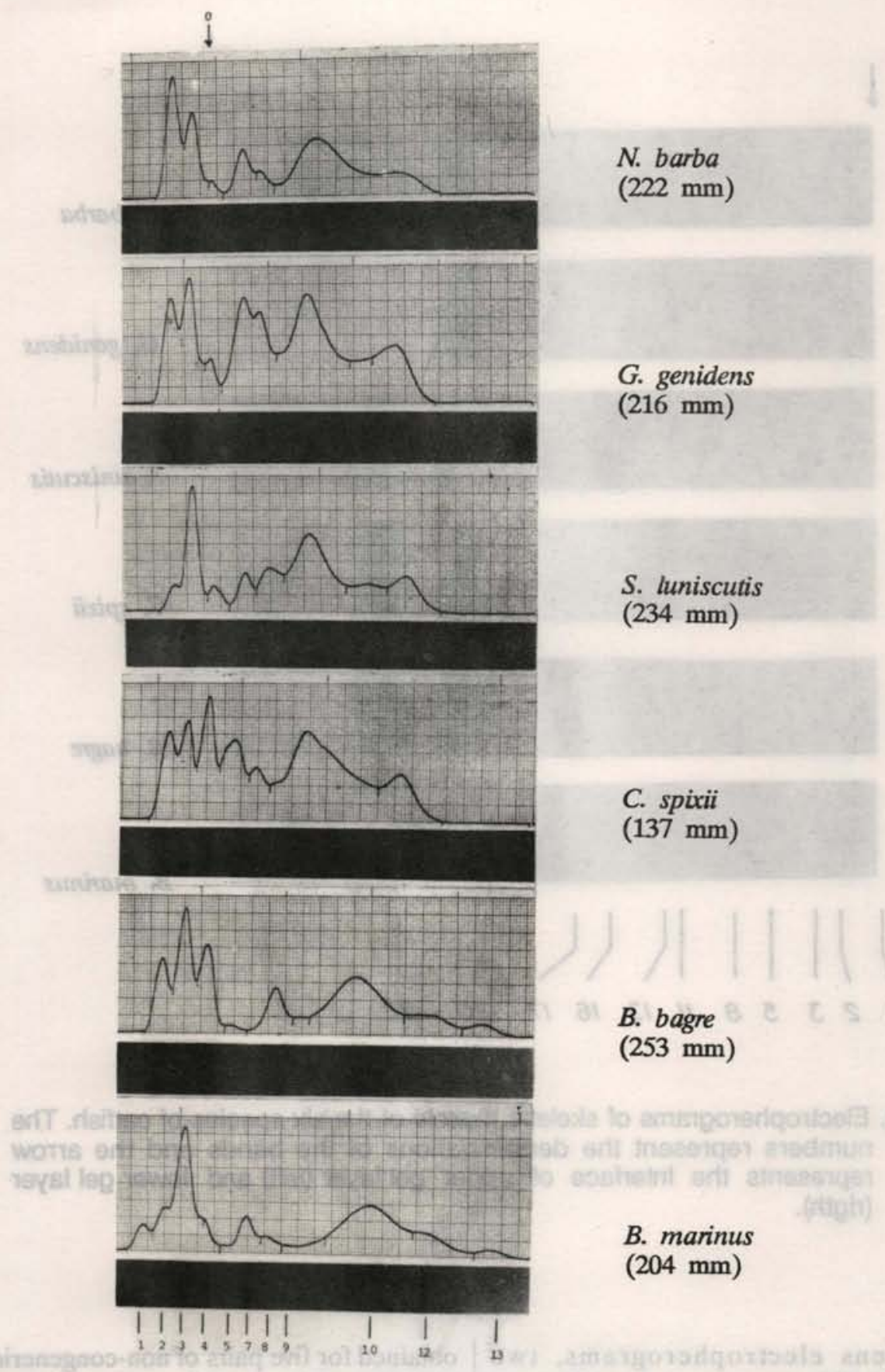

Fig. 1. Densitometric curves and electropherograms of general proteins of eye-lens of the six marine catfishes. The numbers in the bottom represent the denominations of the bands and the numbers in parenthesis are the total lengths of the specimens. 




N. $b a r b a$

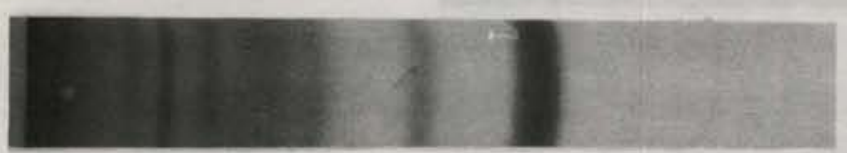

G. genidens

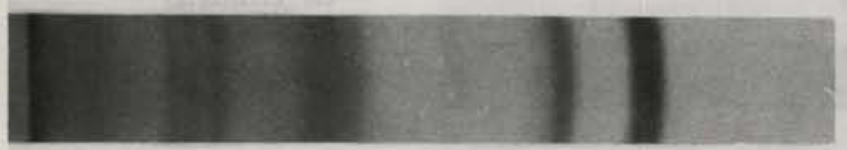

S. luniscutis

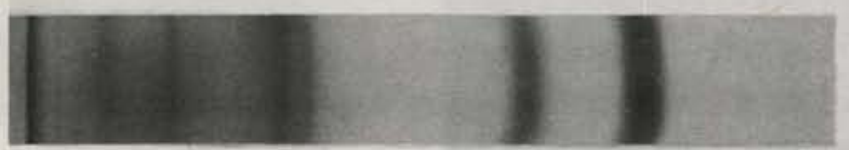

C. spixii

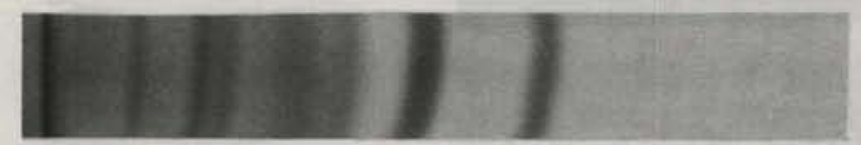

B. bagre

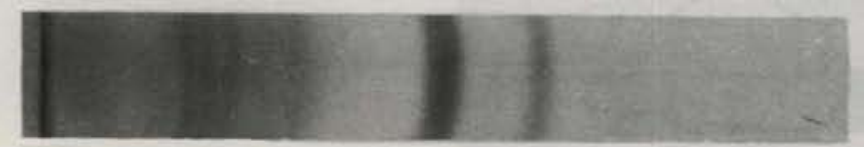

B. marinus

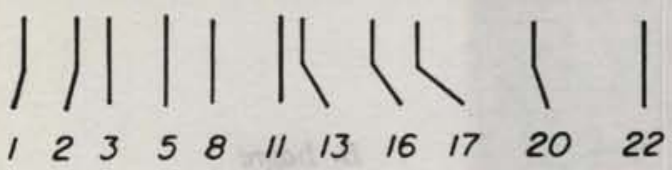

Fig. Electropherograms of skeletic muscle of the six species of catfish. The numbers represent the denominations of the bands and the arrow represents the interface of upper gel layer (left) and lower gel layer (rigth).

Based on eye-lens electropherograms, two dendrograms (Fig. 4a, 4b) were constructed because there were two equal $S$ of highest value in the second matrix, one between the $N$. barba-G. genidens cluster and the species $C$. spixii and the other between the same cluster and the species $S$. luniscutis. This was the only difference between the two dendrograms. The six species were arranged into two main groups. In one group, the $N$. barba-G. genidens cluster joined to C. spixii (Fig. 4a) or to $S$. luniscutis (Fig. 4b). This group joined to another group composed of $B$. bagre and $B$. marinus. The coefficient of similarity between the congeneric species $B$. bagre and $B$. marinus was lower $(\mathrm{S}=0.90)$ than those obtained for five pairs of non-congeneric species, namely $N$. barba and $G$. genidens $(\mathrm{S}=1.0), N$. barba and $S$. luniscutis, $N$. barba and C. spixii, G. genidens and $S$. luniscutis, G. genidens and $C$. spixii $(\mathrm{S}=0.94)$ (Tab. 2).

Based on skeletic muscle electropherograms, two dendrograms were constructed because there were two equal $\mathrm{S}$ of highest value in the third matrix, one between the species $C$. spixii and the $N$. barba - G. genidens cluster (Fig. 5a) and the other between the same species and the B. bagre - B. marinus cluster (Fig. 5b). This was the only difference between the two dendrograms. In both dendrograms, $S$. luniscutis was the most distant species. $N$. barba and G. genidens formed one cluster, and $B$. 
bagre and $B$. marinus formed another. The coefficient of similarity between the congeneric species $B$. bagre and $B$. marinus was lower $(S=0.74)$ than that obtained for two non-congeneric species, namely $N$. barba and $G$. genidens $(\mathrm{S}=0.95)$.

Using the skeletic muscle data combined with the eye-lens data, the composite coefficients of similarity $S$ were computed (Tab. 3). The dendrogram obtained from these composite data is shown in Figure 6. N. barba and $G$. genidens were the most similar pair of species and formed a cluster which is closer to $C$. spixii than to $S$. luniscutis. B. bagre and B. marinus formed the cluster most separated from the other species. As it was observed with eye-lens data, the congeneric species $B$. bagre and $B$. marinus presented again coefficient $S$ which is lower $(S=$ 0.82 ) than that obtained for non-congeneric species, $N$. barba and $G$. genidens $(\mathrm{S}=0.97)$.

\section{Discussion}

All the six ariid species presented ontogenetic variation in electropherograms of eye-lens. The relative concentrations of cathodic or slow migratory bands in alcaline $\mathrm{pH}$ (bands 2 and 3 ), decreased in function of body length. On the other hand, relative concentrations of intermediate migratory $(6,7$ and 8$)$ and anodic or fast migratory bands (11 and 13) increased with the body length. Decreases in relative concentrations of cathodic bands of electropherograms obtained in alcaline $\mathrm{pH}$ were also found in the eye-lens proteins of Mugil cephalus (Peterson \& Shehadeh, 1971) and Micropogonias fumieri (Vazzoler et al., 1985). In the latter there were also increases in the relative concentrations of intermediary and fast migratory bands as observed in the arïd species.

The quantitative variations in electropherograms of eye-lens proteins in function of body length have been explained as a result of transformation of soluble proteins (crystallins) of low molecular weight into insoluble proteins (albuminoids) of high molecular weight (Peterson \& Smith, 1969; Peterson, 1970; Zigman \& Yulo, 1979). The increase in the albuminoid content, however, has been ' considered only relative since the synthesis rate of the soluble proteins decreases during the development of animal (Vazzoler et al., 1985).

In the electropherograms of muscle of the catfishes, decreases in function of body length in the relative concentrations of fast migratory bands, namely band 20 of $N$. barba, G. genidens, C. spixii, B. bagre and $B$. marinus, and band 21 of $S$. luniscutis, were observed. Decreases in the concentrations of fast migratory bands of electropherograms of skeletic muscle were also observed during the growth of Gadus morhua (Connell, 1953), Salmo trutta, S. gairdnerï (Haen \& O'Rourke, 1969), many mugillid species (Herzberg \& Pasteur, 1975) and Micropogonias furnieri (Suzuki et al., 1983b). Neither the causes of these decreases nor the nature of these fast migratory bands are known. However, decreases in the concentration might reflect variations in the rate of protein synthesis and/or mobilization of proteins stored in the muscle (Suzuki et al., 1983b). Another possible explanation is the relation between the decreases in the concentrations and the gonadal development or spawning (Tsuyuki et al., 1962). This probably is not applicable to the case of the catfishes investigated because the variations observed in these species were independent of sex and gonad somatic index.

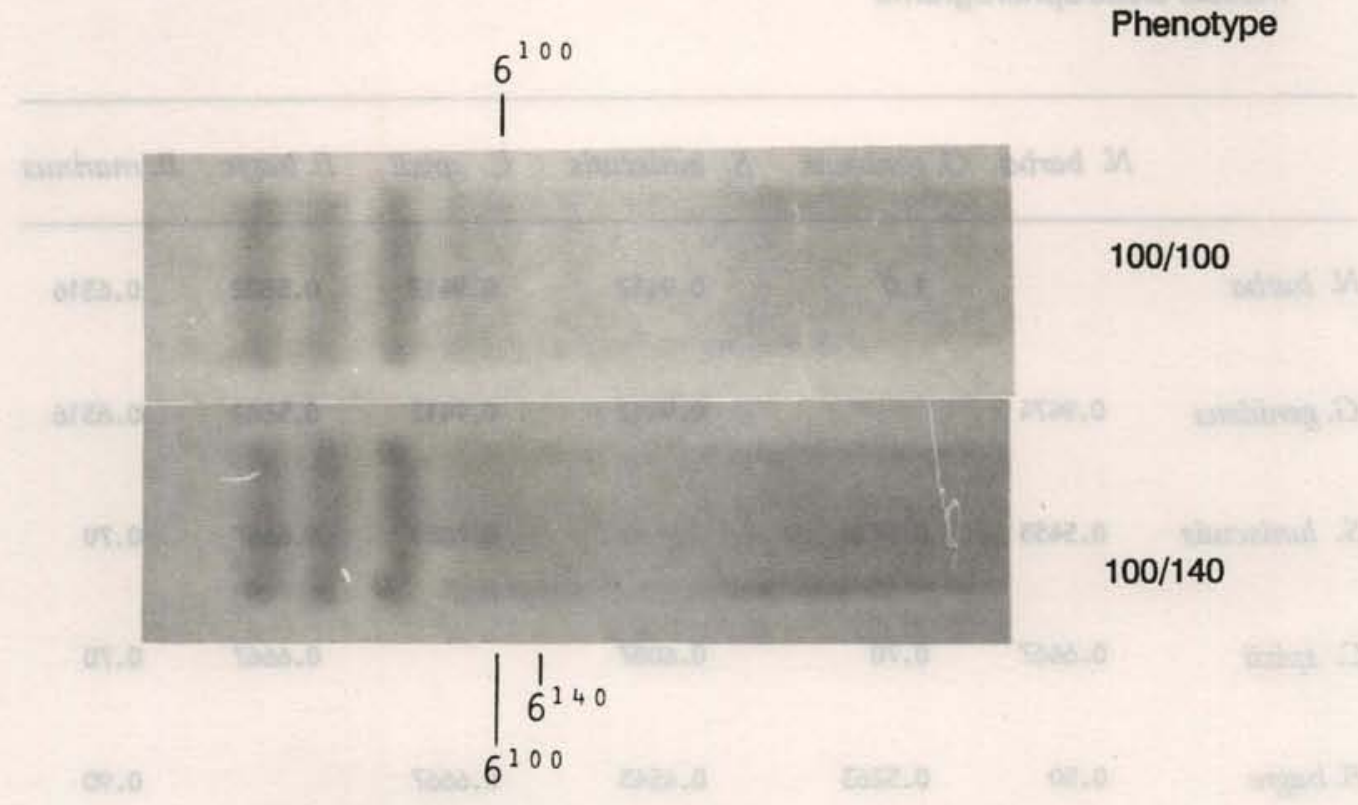

Fig. 3. Polymorphism in band 6 of electropherograms of general proteins of eye-lens of $C$. spixii. The phenotypes 100/100 and $100 / 104$ illustrate the electromorphs $6^{900}$ and $6^{140 .}$ 
Table 1. Frequencies of phenotypes and electromorphs concerning the polymorphism in the band 6 of electropherograms of eye-lens of $C$. spixii

\begin{tabular}{cccccccc} 
Phenotype & Observed & Expected & $x^{2}$ & d.f. & Probability & Electromorph & Frequency \pm standard error \\
\hline $100 / 100$ & 374 & 374.13 & 0.1310 & 1 & $0.80-0.70$ n.s. & $c-6^{100}$ & $0.982 \pm 0.005$ \\
$100 / 140$ & 14 & 13.75 & & & & $c-6^{140}$ & $0.018 \pm 0.005$ \\
$140 / 140$ & 0 & 0.13 & & & & & \\
\hline
\end{tabular}

d.f. = Degrees of freedom

n.s. = non significant at level $5 \%$

Table 2. Coefficient of similarity $S$ between species of marine catfish obtained by the band-counting method (Ferguson, 1980). Above diagonal are the coefficients obtained from data of eye-lens electropherograms and below diagonal, from data of skeletic muscle electropherograms

\begin{tabular}{|c|c|c|c|c|c|c|}
\hline & N. barba & G. genidens & S. huniscutis & C. spixii & B. bagre & B. marinus \\
\hline N. barba & & 1.0 & 0.9412 & 0.9412 & 0.5882 & 0.6316 \\
\hline G. genidens & 0.9474 & & 0.9412 & 0.9412 & 0.5882 & 0.6316 \\
\hline S. huniscutis & 0.5455 & 0.5714 & & 0.8889 & 0.6667 & 0.70 \\
\hline C. spixii & 0.6667 & 0.70 & 0.6087 & & 0.6667 & 0.70 \\
\hline B. bagre & 0.50 & 0.5263 & 0.4545 & 0.6667 & & 0.90 \\
\hline B. marinus & 0.6316 & 0.6667 & 0.5714 & 0.70 & 0.7363 & $2 \operatorname{lat}$ \\
\hline
\end{tabular}




\section{COEFFICIENT OF SIMILARITY}
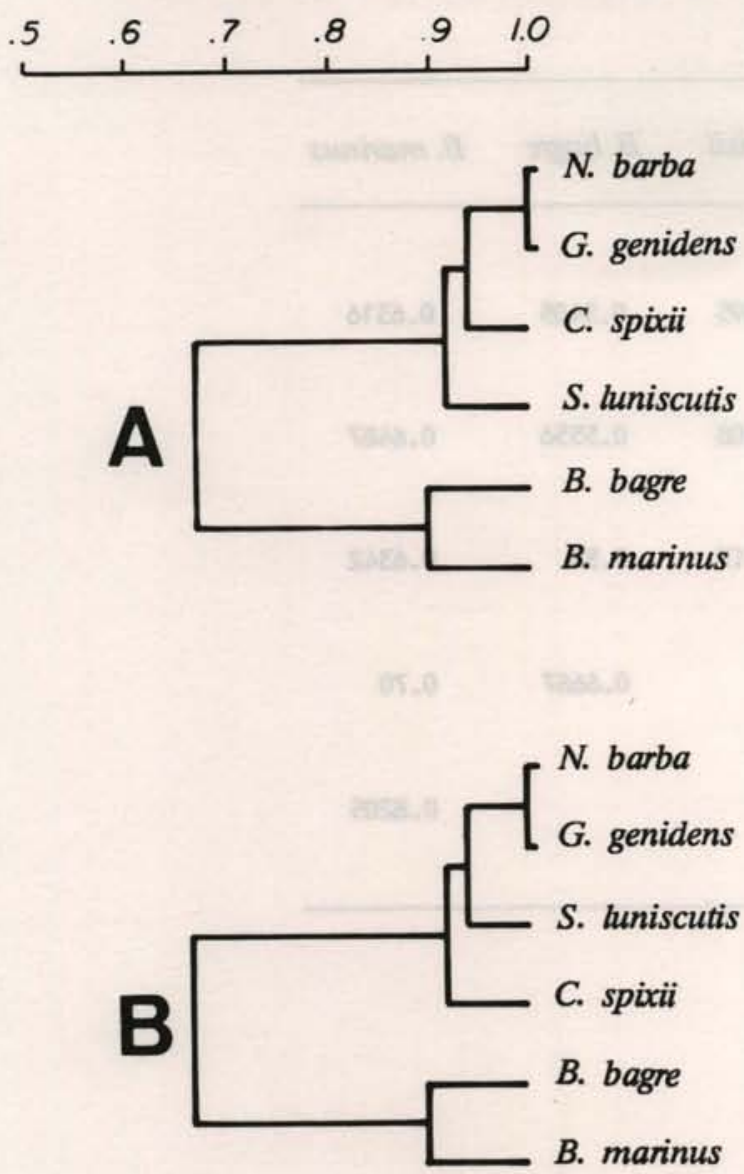

Fig. 4. UPGMA dendrograms showing the relationships among the six marine catfishes, based on coefficients of similarity (Tab. 2) obtained by band-counting method (Ferguson, 1980) from data of eye-lens electropherograms. Two dendrograms, A and $\mathrm{B}$, were constructed because there were two equal $\mathrm{S}$ of highest value in the second matrix.

Genetic polymorphism was not observed in electropherograms of skeletic muscle of the six catfishes. It was found, however, at one locus of the electropherograms of eye-lens of $C$. spixii. Eye-lens proteins which are more polymorphic than muscle proteins were also observed for Salveinus fontinalis (Saunders \& McKenzie, 1971) and species of the genus Cynoscion (Weinstein \& Yerger, 1976).

Regarding interspecific relationships, the congeneric species $B$. bagre and $B$. marinus presented qualitative differences in electropherograms of eye-lens proteins while two non-congeneric species, $N$. barba and $G$. genidens, presented only quantitative differences in electropherograms showing eigth bands with the same

\section{COEFFICIENT OF SIMILARITY}
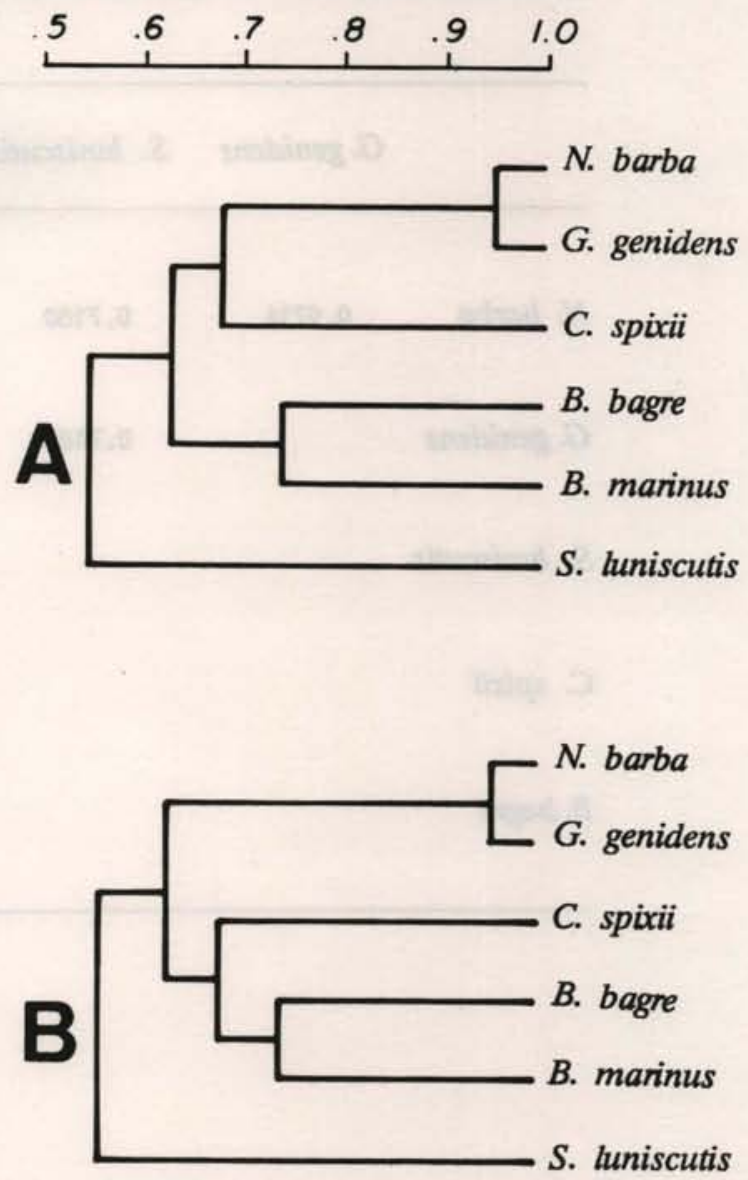

Fig. 5. UPGMA dendrograms showing the relationships among the six marine catfishes, based on coefficients of similarity (Tab. 2) obtained by band-counting method (Ferguson, 1980) from data of skeletic muscle. electropherograms. Two dendrograms, $A$ and $B$, were constructed because there were two equal $S$ of highest value in the third matrix.

electrophoretic mobilities in both species (Fig. 1). In order to know if the qualitative similarity between electropherograms of $N$. barba and G. genidens is manifestation of homoplastic or patristic similarity (Sneath \& Sokal, 1973), a phylogenetic approach for the relationship between these species could be applied.

Two factors which might control quantitative differences in the electropherograms are the regulatory genes which alter the quantity of a certain polypeptide, and differences in affinities of the proteins to the dye resulted from structural differences in the polypeptide chain (Ferguson, 1980). It should also be noted that the proteins studied are non-specific and that there are some limitations in the electrophoretic techniques used, so 
Table 3. Composite coefficient of similarity $S$ between species of marine catfish obtained by the band-counting method (Ferguson, 1980) from data of eye-lens electropherograms combined with those of skeletic muscle electropherograms.

\section{$\begin{array}{lllll}\text { G. genidens } & \text { S. luniscutis } & \text { C. spixii } & \text { B.bagre } & \text { B. marinus }\end{array}$}

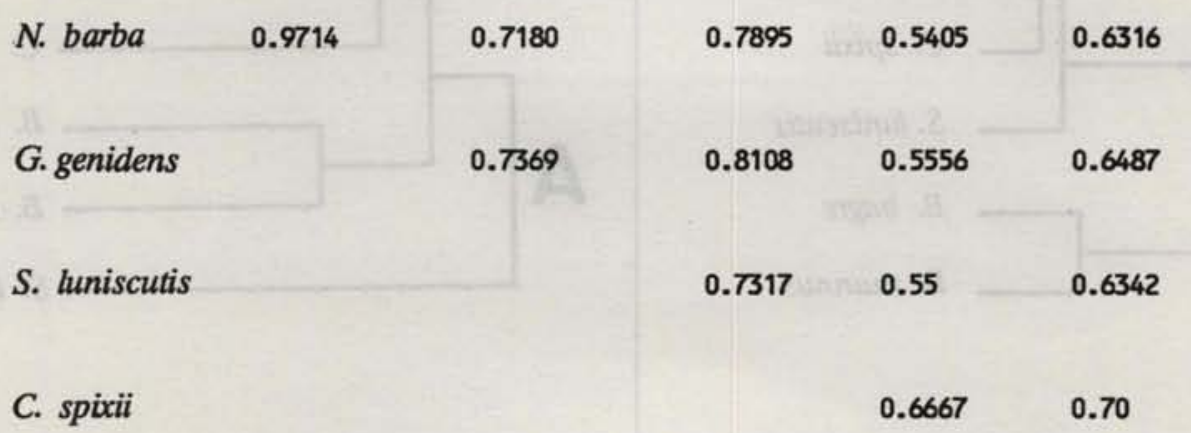

\section{B. bagre}

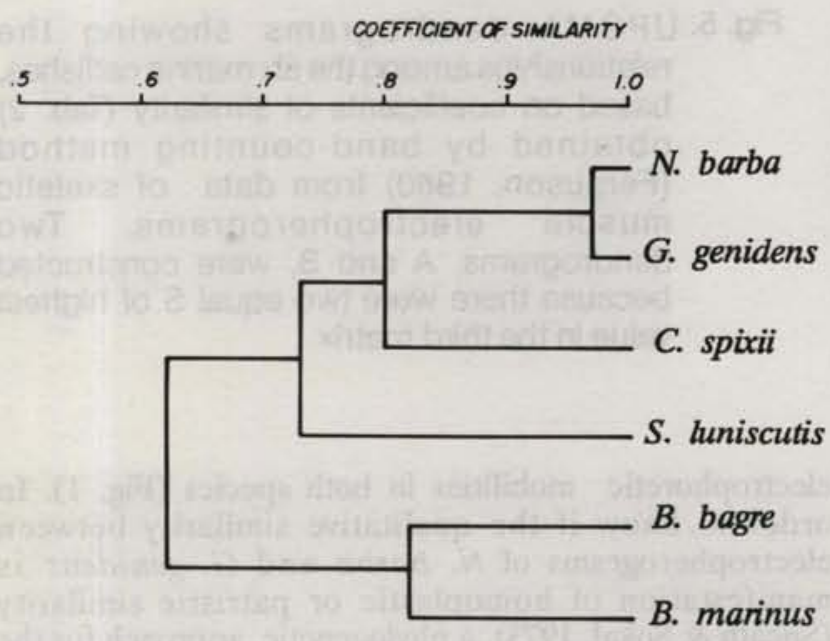

Fig. 6.UPGMA dendrograms showing the relationships among the six marine catfishes, based on composite coefficients of similarity (Tab. 3) obtained by band-counting method (Ferguson, 1980) from data of electropherograms eye-lens electropherograms combined with those of skeletic muscle electropherograms. each band might represent more than one protein which migrate to the same position. This means that the observed quantitative differences might in fact be merely qualitative differences. Quantitative differences in electropherograms of eye-lens proteins have been used to identify various species of fish (Pichot \& Pollard, 1970; Smith, 1970; Pichot, 1973; Weinstein \& Yerger, 1976; Smith \& Gilman, 1982).

Eye-lens is known to be evolutionary conservative (Day \& Clayton, 1973; O'Rourke, 1974; Schmiel \& Guttman, 1974; Tsuyuki et al., 1968; Weinstein \& Yerger, 1976). Regarding the six ariid species investigated, the conservatism of the eye-lens was evident in the coefficients of similarity $\mathrm{S}$ which were higher than those obtained from skeletic muscle data.

The dendrograms obtained from eye-lens data (Fig. 4), skeletic muscle data (Fig. 5) and eye-lens and muscle composite data (Fig. 6) were very similar in general features but they displayed notable differences concerning the position of $S$. luniscutis, $B$. bagre and $B$. marinus. $S$. luniscutis was the most separated species when only the muscle data were considered. On the other hand, when eye-lens data and eye-lens and muscle composite data were considered, $B$. bagre and $B$. marinus, species morphologically and osteologically very distinct from the others (Higuchi, 1982), formed the last branch to join to the rest. 
The hypothesis of nonspecificity (Sneath \& Sokal, 1973) assumes that there are no classes of genes affecting exclusively one class of characters or special regions of organisms. Thus, similar numerical classifications would be expected even when the characters were sampled from two different regions of the body and analyzed separately. One of the limitations of this hypothesis is that its argument depends on the assumption of the ample pleiotropy in the genoma (Farris, 1971). Our results concerning different arrangements of catfish species in the dendrograms obtained from eye-lens and skeletic muscle data do not agree with this hypothesis. Rather our results suggested that the genes affecting the eye-lens and the muscle proteins could be more or less independent of each other.

In organisms distantly related like members of distinct genus, more than one electrophoretically detectable substitution in the codon per locus might occur without giving any clue of the sequence of changes (Nair et al., 1971). Thus, one substitution that affects the protein charge might cancel the effect of another substitution and enhance the chance of two different proteins to present the same mobility (Case \& Wake, 1975; Bruce \& Ayala, 1979; Ferguson, 1980). Consequently, proteins of slow evolutionary rate are of greater value in studies on taxonomic relationships at supraspecific level (Ferguson, 1980; Tsuyuki et al., 1968). Analyses of general proteins which have relatively fast evolutionary rate (Sarich, 1977) might have interfered in the incongruences observed in the dendrograms of the six species of catfish belonging to five genus.

Although no study concerning phylogenetic relationships among the six catfishes of the present paper is known, comparisons of osteological characteristics of catfishes are found in Higuchi (1982). The author described a series of osteological characteristics of $N$. barba, $N$. planifrons, G. genidens, $S$. luniscutis and $C$. spixii, and recognized three groups. The first group, represented by $C$. spixii, shows compact and slight skull and some characteristics which apparently indicate primitiveness and distinguish this group from the others. The second group, represented by $S$. luniscutis, shows a bulky skull, stronger scapular girdle and some characteristics which resemble those of the first and the third groups. The distinctness of $C$. spixii and the intermediate position of $S$. luniscutis as found in osteological study can also be seen in one of the two dendrograms obtained from electropherograms of eyelens data (Fig. 3b). The third group, composed of $N$. barba, G. genidens and $N$. planifrons, presents thick ossification and voluminous and heavy skull. The dendrograms obtained by us agree with this osteological investigation regarding the clustering of $N$. barba and $G$. genidens. There were no $N$. planifrons in our samples while $B$. bagre and $B$. marinus were not included in Higuchi's study. In our dendrograms the two congeneric species, $B$. bagre and B. marinus, composed a distinct group but their coefficient of similarity was lower than those of many pairs of non-congeneric species. This low coefficient of similarity corroborates the necessity of a revision in the systematics at supra-specific levels of the family Ariidae as pointed out by Higuchi (1982) and Higuchi et al. (1982).

\section{Resumo}

Eletroforeses de proteínas gerais de cristalinos e de músculo esquelético de seis espécies de bagres marinhos foram realizadas, respectivamente, em membranas de acetato de celulose e em géis de poliacrilamida. Polimorfismo genético ocorreu apenas em um locus de eletroferogramas do cristalino de Cathorops spixii. Variaçōes ontogenéticas nas concentraçōes relativas das bandas foram observadas nos eletroferogramas do cristalino e do músculo esquelético. As seis espécies de bagres marinhos podem ser identificadas através das diferenças quantitativas e qualitativas nos eletroferogramas. Coeficientes de similaridade foram determinadas pelo método de contagem de bandas e dendrogramas UPGMA foram construídos para ilustrar as relaçōes interespecíficas entre as espécies.

\section{Acknowledgements}

We are grateful to Dr. Vicente Gomes and Mrs. Maria José A. C. R. Passos for their aid in sampling and laboratory analyses. This work was supported by grants from FAPESP (80/1694-0) and CNPq (10.1739/82 and $40.0528 / 82)$.

\section{References}

BRUCE, E. J. \& AYALA, F. J. 1979. Phylogenetic relationships between man and the apes: electrophoretic evidence. Evolution, 33:1040-1056.

CALHOUN, W. B. \& KOENIG, V. L. 1970. The distribution of the soluble proteins in the lens of some marine vertebrates. Comp. Biochem. Physiol., 34: 71-80.

CARVALHO, J. P. 1941. Nota preliminar sobre a fauna ictiológica do litoral sul do Estado de São Paulo. Bolm Indúst. Anim., n.s., São Paulo, 4: $27-81$.

CASE, S. M. \& WAKE, M. H. 1975. Electrophoretic patterns of certain proteins in caecilians (Amphibia:Gymnophiona). Comp. Biochem. Physiol, 52B:473-476.

CHAUVET, C. \& BAETEN, S. 1983. Étude comparée de deux populations tunisiennes de daurades (marine et lagunaire): analyse électrophoretique des cristallins. Rapp. P.-v. Reún. Comm. int. Explor. scient. Mer médit., 28:169-170.

CONNELL, J. J. 1953. Studies on the proteins of fish skeletal muscle. 2. Electrophoretic analysis of low ionic strength extracts of several species of fish. Biochem. J., 55:378-388.

DAY, T. H. \& CLAYTON, R. M. 1973. Intraspecific variation in the lens proteins. Biochem. Genet., 8: 187-203. 
ECKROAT, L. R. 1971. Lens proteins polymorphisms in hatchery and natural populations of brook trout, Salvelinus fontinalis (Mitchill). Trans. Am. Fish. Soc., 100:527-536.

1973. Allele frequency analysis of five soluble protein loci in brook trout, Salvelinus fontinalis (Mitchill). Trans. Am. Fish. Soc., 102: 335-340.

\& WRIGHT, J. E. 1969. Genetic analysis of soluble lens protein polymorphism in brook trout, Salvelinus fontinalis. Copeia, (3):466-473.

ETTABILI, M.; BIAZ, R.; BELVEZE, H. \& BELEMLIH, A. 1980 . Identification of Moroccan Atlantic coast sardines by electrophoresis on polyacrylamide gel.In: Frigerio, A. \& McCamish, M., eds Recent developments in chromatography and electrophoresis. Amsterdam, Elsevier. v.10, p. 83-87.

FARRIS, J. S. 1971. The hypothesis of nonspecificity and taxonomic congruence. A. Rev. Ecol. Syst., 2: 277-302.

FERGUSON, A. 1980. Biochemical systematics and evolution. Glasgow, Blackie. 194p.

FIGUEIREDO, J. L. \& Menezes, N. A. 1978. Manual de peixes marinhos do sudeste do Brasil. II. Teleostei (I). São Paulo. Museu de Zoologia da Universidade de São Paulo. p.34-39.

FOWLER, H. W. 1941. A list of the fishes known from the coast of Brazil. Arq. Zool. Est. S Paulo, 3: 115-185.

1951. Os peixes de água doce do Brasil. Arq. Zool. Est. S Paulo, 6:405-625.

GORNALL, A. C.; BARDAWILL, C. S. \& DAVID, M. M. 1949. Determination of serum proteins by means of biuret reaction. J. biol. Chem., 177:751-766.

GOSLINE, W. A. 1945. Catálogo dos nematognatos de água-doce da América do Sul e Central. Bolm Mus. nac., Zool., Rio de Janeiro, (33):1-138.

HAEN, P. J. \& O'ROURKE, F. J. 1969. Comparative electrophoretic studies of water-soluble muscle proteins of some Irish freshwater fishes. Proc. R. Ir. Acad., 68B:101-108.

HERZBERG, A. \& PASTEUR, R. 1975. The identification of grey mullet species by disc electrophoresis. Aquaculture, 5:99-106.

HIGUCHI, H. 1982. Estudo osteológico de bagres marinhos do litoral sul do Brasil (Osteichthyes: Siluroidei: Ariidae). Dissertação de mestrado. Universidade de São Paulo, Instituto de Biociências. $135 \mathrm{p}$.
HIGUCHI, H.; REIS, E. G. \& ARAÚJJ, F. G. 1982. Uma nova espécie de bagre marinho do litoral do Rio Grande do Sul e consideraçōes sobre o gênero nominal Netuma Bleeker, 1858 no Atlântico Sul Ocidental (Siluriformes, Arïdae). Atlântica, Rio Grande, 5:1-15.

LLEONART, J. \& AGELL, O. 1980. Taxonomía numérica del género Merluccius (Rafinesque, 1810) a partir de la electroforesis del miógeno. Investigación pesq., Barcelona, 44:461-470.

NAIR, P. S.; BRNCIC, D. \& KOJIMA, K. I. 1971. II. Isozyme variations and evolutionary relationships in the mesophragmatica species group of Drosophila. Studies in Genetics VI. Univ. Texas Publs, (7103):17-28.

O'ROURKE, F. J. 1974. Fish. In: Wright, C. A., ed. Biochemical and immunological taxonomy of animals. London, Academic Press. p. 243-302.

PAYUSOVA, A. N. \& TSELIKOVA, T. N. 1981. Differentiation of populations of grass carp, Ctenopharyngodon idella, silver carp, Hypophthalmichthys molitrix and bighead, Aristichthys nobilis, from electrophoresis myogens. J. Ichthyol., 21:23-30.

PETERSON, G. L. 1970. The effect of urea on solubility and electrophoretic characteristic of protein from eye lens nucleus of four shark species and a teleost. Comp. Biochem. Physiol., 35:299-302.

\& SHEHADEH, Z. H. 1971. Subpopulation of the Hawaiian striped mullet Mugil cephalus: analysis of variation of nuclear eye-lens proteins electropherograms and nuclear eye-lens weights. Mar. Biol., 11:52-60.

\& SMITH, A. C. 1969. Intraspecific variation in the soluble nuclear eye lens proteins of the sandbar shark Carcarhinus milberti (Muller and Henle). Comp. Biochem. Physiol., 31:679-684.

PHAN, V. N.; SUZUKI, H.; GOMES, V. \& PASSOS, M. J. A. C. R. 1985. Notes on electropherograms of eye-lens, muscle proteins and zymograms of muscle esterases of fish collected during the First Brazilian Expedition to the Antarctica. Bolm Inst. oceanogr., S Paulo, 33(2):201-212.

PICHOT, P. 1973. Étude sérologique et biochimique de trois espèces de merlus $M$. merluccius (L.), $M$. senegalensis Cadenat, $M$. cadenati Doutre. Revue Trav. Inst. Pêches marit., 37:233-247.

\& Pichot, Y. 1973. Caractères biochimiques de certaines espèces de Scombridés. Revue Trav. Inst. Pêches marit., 37:249-252. 
PICHOT, P. \& POLLARD, D. A. 1970. Étude électrophorétique des protéines du cristallin de sparidés et centracanthidés méditerranéens. Revue Trav. Inst. Pêches marit., 34:81-88.

POLI, C. R. 1973. Os bagres do litoral de Santa Catarina e Rio Grande do Sul - Brasil (Ostariophysi, Siluriformes, Bagridae). Iheringia, Zool., (42):3-13.

PUYO, J. 1949. Poissons de la Guyane Française. Paris, Office de la Recherche Scientifique Outre-Mer. 280p.

RIBEIRO, A. M. 1911. Fauna brasiliense: peixes. Arch. Mus. nac., Rio de Janeiro, 16:284-298; 338-352.

SARICH, V. M. 1977. Rates, sample sizes, and the neutrality hypothesis for electrophoresis in evolutionary studies. Nature, Lond., 265:24-28.

SAUNDERS, L. H. \& McKENZIE, J. A. 1971. Comparative electrophoresis of Arctic char. Comp. Biochem. Physiol., 38B:487-492.

SCHMIEL, C. V. \& GUTTMAN, S. I. 1974. An electrophoretic analysis of the lens and muscle proteins of selected anurans. Am. Midland Naturalist, 91:148-159.

SCOPES, R. K. 1968. Methods for starch gel electrophoresis of sarcoplasmic proteins. An investigation of the relative mobilities of the glycolytic enzymes from the muscle of a variety of species. Biochem. J., 107:139-150.

SMITH, A. C. 1965. Intraspecific eye lens protein differences in yellowfin tuna, Thunnus albacares. Calif. Fish Game, 51:163-169.

1969. Protein variations in the eye lens nucleus of the mackerel scad (Decaptenus pinnulatus). Comp. Biochem. Physiol., 28:1161-1168.

1970. Electrophoretic, solubility and thermostability differences in proteins of eye lens nuclei from two closely related fish species, the yellowfin tuna and the bigeye tuna. Comp. Biochem. Physiol, 33:1-14.

1971. The soluble proteins in eye lens nuclei of albacore, bluefin tuna and bonito. Comp. Biochem. Physiol., 39B:719-724.

\& GILMAN, R. L. 1982. Electrophoretic study of proteins from solubilized eye lens nuclei of fishes. Comp. Biochem. Physiol., 71B:337-343.

\& GOLDSTEIN, R. A. 1967. Variation in protein composition of the eye lens nucleus in ocean whitefish, Caulolatilus princeps. Comp. Biochem. Physiol., 23:533-539.
SNEATH, P. H. \& SOKAL, R. R. 1973. Numerical taxonomy. San Francisco, W. H.Freeman. 573p.

SUZUKI, H.; VAZZOLER, A. E. A. de M. \& PHAN, V. N. 1983a. Estudo eletroforético de proteínas de músculo esquelético de Micropogonias furmieri (Desmarest, 1823) da costa SE-S do Brasil. 1. Consideraçōes técnicas. Bolm Inst. oceanogr., S Paulo, 32(2):153-165.

1983b. Estudo eletroforético de proteínas de músculo esquelético de Micropogonias furnieri (Desmarest, 1823) da costa SE-S do Brasil. 2. Variaçāo ontogenética e estudo populacional. Bolm Inst. oceanogr., S Paulo, 32(2):167-176.

TANIGUCHI, N. \& ISHIWATARI, T. 1972. Inter and intraspecific variations of muscle proteins in the Japanese crucian carp. I. Cellulose acetate electrophoresis pattern. Japan. J. Ichthyol., 19: 217-222.

TAYLOR, W. R. \& MENEZES, N. A. 1977. Ariidae. In: Fischer, W. ed. FAO species identification sheets for fishery purposes. Western Central Atlantic (fishing area 31). Rome, FAO. v.1.

TOMMASI, L. R. 1965. Lista dos bagres marinhos e de água salobre do Brasil. Contrçōes Inst. oceanogr. Univ. S Paulo, sér. Oceanogr. biol., (10):1-11.

TSUYUKI, H.; ROBERTS, E. \& GADD, R. E. A. 1962. Muscle proteins of Pacific salmon (Oncorhynchus). III. The separation of muscle proteins soluble in low ionic strength salt solutions by starch gel electrophoresis. Can. J. Biochem. Physiol., 40: 929-936. UTHE, J. F. \& CLARKE, L.W. 1967. Comparative electropherograms of the family Catostomidae. J. Fish. Res. Bd Can., 24:299-304.

; LOWE, R. H.; HADAWAY, 'W. \& WESTRHEIM, S. J. 1968. Contribution of protein electrophoresis to rockfish (Scorpaenidae) systematics. J. Fish. Res. Bd Can., 25: 2477-2501.

;

\& VANSTONE, W.

E. 1965. Comparative zone electropherograms of muscle myogens and blood hemoglobins of marine and freshwater vertebrates and their application to biochemical systematics. J. Fish. Res. Bd Can., 22: 203-213.

VAZZOLER, A. E. A. DE M.; PHAN, V. N.; DEMASI, W. M. T.; SUZUKI, H. \& GOMES, V. 1985. Micropogonias furnieri (Desmarest,1823): estudo quali-quantitativo da variação ontogenética do padrão eletroforético de proteínas gerais do cristalino. Bolm Inst. oceanogr., S Paulo, 33(2): 121-137. 
WEINSTEIN, M. P. \& YERGER, R. W. 1976. Protein taxonomy of the Gulf of Mexico and Atlantic Ocean seatrouts, genus Cynoscion. Fishery Bull. natn. mar. Fish. Serv., 74:599-607.

WESTRHEIM, S. J. \& TSUYUKI, H. 1967. Sebastodes reedi, a new scorpaenid fish in the Northeast Pacific Ocean. J. Fish. Res. Bd Can., 24:1945-1954.

YAMAZOE, Y. 1981. Comparative electropherograms of muscle proteins of amphibious fishes. Bull. japan. Soc. Scient. Fish., 47:1047-1049.
ZIGMAN, S. \& YULO, T. 1979. Eye lens ageing in the dogfish (Mustelus canis). Comp. Biochem. Physiol, 52B:379-385.

(Received 17-Nov-88; accepted 08-Aug-90) 